\title{
The reign of unholy trinity in Borno state
}

\begin{abstract}
This paper seeks to explore the reign of unholy trinity in Borno state which was decomposed as bokoharam, Internal Displaced Persons (IDPs) and Illicit Money. The paper reveals that the activities of the insurgents gave rise to this menace in the state which has caused havoc on the residents, properties and socio- economic activities of the state. The study concluded that stakeholders that should be at the forefront in resolving this unhealthy situation are using it as a conduit pipe to enrich themselves, thus making it difficult to end the activities of the insurgence. The study further recommends that security operatives should operates within the rules of engagements, politicians as well as residents should be patriotic and give useful information for intelligence gathering, stake holders caught in illegal activities should be dealt with appropriately, Jobs should be created, and women should be empowered and trained to be self employed etc.
\end{abstract}

Keywords: boko Haram, trinity, IDP's, insurgency, intelligence, cripple, economic, federal, resources, generation, increased
Volume 2 Issue 6 - 2018

\section{Ibrahim Mohammed Lawal}

Department of Social Sciences \& Economics, University of Maiduguri, Nigeria

\begin{abstract}
Correspondence: Ibrahim Mohammed Lawal, Department of Social Sciences \& Economics, University of Maiduguri, Borno State, Nigeria, Tel +234 (0)7031325328, 08025599503,
\end{abstract} Email ibnaval2002@yahoo.com, ibrahinruqqy@gmail.com

Received: March 28, 2018 | Published: November 20, 2018

\section{Introduction}

Borno state came into existence on 03rd, February, 1976 after it was carved out from the North Eastern States. It has 27 LGAs' and shares boundaries with Niger, Chad, Cameroon, Adamawa, Gombe and Yobe. The state has a population of about 5,925,668 and ranked 12 out of the 36 states of the country. Agriculture and livestock farming is considered as the major activities of the residents. The state has a GDP of $\$ 5.18 \mathrm{~B}$ with a per capita income of $\$ 1,214$ with an acronym called "Home of Peace" which it has demonstrated in the past apart from the Maitasine crisis of 1980's and other minor religious and political crisis or riot, though they were all contained within a shortest period of time. But what finally succeeded in threatening the peace of the state was the Boko Haram crisis which started in 2009 and this has created a lot of issues or tensions in the state. Amongst which are; it has lead to loss of lives and properties in the state, it has cripple the economic activities of the state, causes inflation due to deficiency in supply side, food insecurity, decline in investment activities, decline in internal revenue generation, increased rate of crime, destruction of the population structure as more of the people mostly affected were youths, unemployment, migration of residents, decline in the level of education, political tools, milking of the state and federal resources, increased the infrastructural gap and it has increased poverty, Hunger and one form of illness (Malnutrition, HIV/AIDs) etc in the state. Despite, all this negative implication the insurgency has caused the state, it has become a conduit pipe for wealth creation amongst unpatriotic stakeholders at all levels and this has goes a long way to affect the rate in which the activities of insurgent will be conquered. It is against this background that this work was carried out and coined as "The reign of unholy trinity in Borno state".

\section{Unholy trinity in borno state}

The concept of unholy trinity was re-coined from the biblical" Holy Trinity". Though this was used because of the connectivity, interrelationship and interdependence that exist amongst the concept involved in the discussion. The Unholy trinity is as thus; Bokoharam, Internally Displaced Persons (IDP's) and Illicit wealth.

\section{Boko haram}

Boko Haram is a nickname that was labeled to a militant group which in Hausa means "Western education is a sin", is a jihadist militant organization based in the northeast of Nigeria, North Cameroon and Niger. The group original name is "Congregation and People of Tradition for Proselytism and Jihad". It is an Islamist movement which strongly opposes man-made laws and Westernization. It was founded by Mohammed Yusuf. This was a movement that started in 2001 but later gained momentum. The inability of the government to proactively contained the group at their early stage lead to the crisis in 2009 despite reports. This crisis resulted to the death of about 20,000 citizens, over $1 \mathrm{M}$ displaced persons and properties (ies) worth $\$ 5.9 \mathrm{~b}$ were lost. Though, the crisis still persists once in a while but not as compared from the period of 2009 to early 2015 when it was almost a daily affair. Boko Haram is like a "chameleon" as it has so many colorations' such as religious, political, government and international colors. This makes it complex in understanding the whole dynamics of their activities.

By and large, the effect of the crisis is multidimensional such as economic, political, socio-economic effect on the state economy. From the economic view point; it has crippled the economic (business) activities of the state, inflation on the increase due to supply deficit, food insecurity, lack of investments, decline in the state revenue, lack of improvement in infrastructural development etc. The socioeconomic implication is that it has lead to increase in crime rate, destruction in the population structure, unemployment, migration, illiteracy rate etc. Also, the political implication is that citizen were disenfranchise during election, political killings under the guise of insurgency etc. Despite, all the negative impacts of this insurgence, some individuals within and outside the state are comfortable with the crisis to continue as they are busy siphoning tax payers' money to their personal pocket under the disguise of fighting or funding the insurgence. For instance the Dasuki Arms deal of $\$ 2.1 \mathrm{~b}$ etc. Thus, Boko Haram is considered as a franchise. This raise the questions of whether will the beneficiaries from this franchise allow the insurgency to end?

\section{Internally displaced persons (IDPs)}

The activities of the insurgence has resulted to the displacement of over $1.7 \mathrm{M}$ residents in about 20 LGA's of the state while about $4 \mathrm{M}$ are faced with food insecurity. With this figure of IDPs, the state is now considered third position globally after Syria and Afghanistan.1 The worrisome part of this insurgency is the increase number of 
internally displaced persons which are mostly women and children accompanied with different illness. They have become refugee in their own country. This situation has become burdensome on the part of government because the state spends about N3.5M daily and about N600M on monthly basis.2,3 With this huge amount spent on IDPs, it does not commiserate with their welfare as there are cases of hunger, malnutrition and other illness. This is evidence from the UN Report that 120,000 children may die next year due to hunger in the IDP camps.4 Also, there are also cases of HIV in the camp of about 3,800 new cases which is about $2.5 \%$ of the total victims in the state and 70 of them are children. 5 Despite, this sympathetic situation been faced by the IDPs, some individuals are now using them as a franchise. They end up siphoning their foods and other items to the market and converting it to cash and also for their personal use. And at the end, these officials that public trust has been bestowed on them lives a luxury life style above their monthly salary while the IDPs live in squalor. For instance the Rice \& Saudi Dates Saga etc. But the question is how did these items get to the market? If there are no insider related conspiracies. One fact remains that anybody that thinks he or she is benefiting from this act is busy deceiving him or herself and they should have at the back of their mind that they will be held accountable on the Day of Judgment because the wealth they thought they are amazing is like a "blood money". Thus, the need for all stakeholders to be patriotic in handlings all resources of this IDPs judiciously and see them as their immediate family...Love for others what you love for yourself.

\section{Illicit wealth}

The Boko Haram and the IDPs are now considered as a venture. i.e as a source of making money " the so called Blood Money". The stakeholders involved want to take advantage of the situation to make money. Please note that in all the stakeholders, there is always a Judas and it's the Judas that this piece will be referring to because their actions have beclouded the air. The stakeholders can be decomposed as thus:

Security operatives: Well kudos to them for scarifying their lives for our safety. Though some of them are not patriotic because corruption has permeated the ranks \& files of its various structures in the fight against insurgency. Thus, they are using this insurgence to make money as they engage in diverting funds or short changing their juniors officers, trading in fish, beans etc, extortion of money from traders and commuters etc. Maiduguri is now like "ATM" because they are sure of making money from here at whatever cost rather than concentrating on their primary assignment in restoring peace. The question that comes to mind, is that those that are benefiting from this insurgence, will they allow it to end? Because when it ends, they will all be return back to their various destinations.

Government \& politician: The Government or its officials is not spared in this because the Judas amongst them are pretending under this insurgence to siphon government funds and even food and other items in favour of the IDPs to their personal pockets.4,6 This is a great sign of mistrust and they will be held accountable on the Day of Judgment. This warning signals can be viewed from the fact that despite all the huge sums spent on them, donations received from well meaningful Nigerians within and outside the country, from NGOs, etc it does not commiserate with the welfare of this IDPs as they still live in hunger, poverty etc. This depicts that something is wrong somewhere? In addition, the politicians are also not saints as they are also benefiting directly or indirectly, thus the need for all to be patriotic since we just have one state called Borno irrespective of party differences and if they are no people who will they governor who will vote for them in the future. Mind us, we shall all be called upon to account for our deeds on the day of judgement. NGOs: The NGO's are also doing their best, Kudos to them but their best is still not enough considering the condition in which the IDPs are in and comparing it to the total number of NGOs that are present in the state (about 126 NGOs). This also creates a vacuum that something is also wrong. In the words of Gov The huge chunk of what they (NGOs) are budgeting for Borno goes to service overheads", The NGO are in the habit of using the name of Borno to make money and enrich themselves", "we have become cash cow", People are smiling their ways to the bank from the agony of our people. This is unacceptable.7 This implies that they only end up enriching themselves i.e living a luxury life at the expense of the IDPs. This further raise questions that will they also allow this situation to end since the insurgence is now their employer? In fact most of them go a long way to rent house for up to more than 2 years. Why? Is that how the situation will continue for those years? Consequently, if the insurgence ends, they will be expected to return back and all jobs will be lost because their donors will no longer fund them.

Residents (Civilians) of the State: The residents of the state have a major role to play in terms of assisting both the government and security operatives in giving relevant information of their (Boko Haram) activities. But the reverse is the case. Some of these residents now either conspires with the insurgents or security operatives (Judas amongst them) in as far as they are making money. i.e In as far they have their own share of the money, everybody should go to hell" This is not patriotism. Only few residents are truthful and patriotic to the security personal so as to bring an end to this insurgence. For instance, some individuals suppress key information's that could be of assistance to security operatives while other gives the Boko Haram information, hide their weapons to enable them attack. In addition, some even conspire with these government officials to buy this items meant for the IDPs in exchange for cash and also engaging into trade with this categories of security operatives, knowing fully that it's not a legitimate trade. This is inhuman, hence the need for all of us to be patriotic and to detest from the activities of this Judas amongst the security personnels, government officials etc whenever they come to them with such deals.

\section{Conclusion}

In conclusion, Boko Haram, IDPs' and illicit wealth is considered as unholy trinity in the state because none of it have impacted positively on the entire lives of the people rather it worsen the situation of the state. Therefore, there is the need for all stakeholders to retrace their footsteps and be patriotic towards bringing an end to this insurgency. Life is being lost, people are starving, homeless, do not have access to key facilities that would make life meaningful to them but others seems to take advantage of the situation to amaze wealth and they are being celebrated. This is uncalled for but mind you it's a Blood Money and you must account for it on the day of judgment whether you like it or not. Today is their turn, tomorrow might be yours or any of your relatives, and will you be happy if they are faced with such situation? Therefore...Love your neighbor as you love yourself. Let's all try and be patriotic towards bringing an end to these ugly phenomena called Boko Haram rather than making it a franchise.

\section{Recommendations}

From the foregoing, below are the recommendations so as to tackle this menace in the state. Security operatives are to ensure that they carry out their assignments professionally and within the confined of their rules of engagements. Security operatives are to 
establish community relations scheme for them succeed in their operations. The BOSG should have a roadmap on the areas where the NGOs' services is highly required and also to share tasks according to the objectives of this NGO's. This is done to avoid too much concentration of various NGO on a particular issue.

The NGOs should work alongside with relevant ministries that tally with their core objectives so that progress report can be easily ascertained on their activities.

The NGOs should endeavor to bring in their food stuffs from nearby states so that the supply deficit in food stuff can be filled. This will further results to a reduction in price of food items.

Government should ensure that the perpetrators of this crimes face the wrath of the law as nobody should be given preferential treatment because it will serve as a detriment to others.

a) Government should create jobs for the teeming unemployed youths in the state by establishing Skills acquisition programs so that they will be trained \& be employer of labour.

b) Government should also revive the agricultural sector by bringing in modern technology in agriculture-Mechanized agriculture so that the teeming unemployed youth can be gainfully employed.

c) Government should disburse loans to trainees to trained IDPs on Small scale business so that they can set up their own businesses.

d) Security operatives are to ensure that the identity and security of informants are highly protected as this will boast intelligence gathering.

e) BOSG and other partnering agencies should provide medical facilities as well as educational facilities to the IDPs so that they can live normal lives. f) High powered committee should be set up to monitor the activities of the IDPs so as to ensure that all resources are adequately expended as this will to some extent mitigate possible diversion.

\section{Acknowledgements}

None.

\section{Conflict of interest}

The author declares that there is no conflict of interest.

\section{References}

1. Economic Confidential. Dangote donates N2billion to Borno IDPs. 2016.

2. Premium times nigeria. Borno Spends N600M to feed people displaced by Boko Haram. 2015.

3. Terab. We spent N3.5M daily on IDPs. 2015.

4. Punchng. Time bomb: Borno IDP camps of hunger, malnourishment and death...120,000 children may die of hunger in IDP camps next yearUN. 2016.

5. Pulseng. HIV; 3,800 Infected in Borno IDPs Camp. 2017.

6. Sahara Reporter. Dangote donate N2B to aid IDPs Living in Borno State. 2016.

7. International Centre for Investigative Reporting. Borno Governor Attacks Aid Agencies, NGOs Again. 2017. 